\title{
The Sociological Implication of State Creation in Nigeria And The Means of Resolving The Unforeseen Dispute
}

\author{
${ }^{1}$ Emily Akintoye and ${ }^{2}$ Sunday Okungbowa Uhunmwuangho \\ ${ }^{1}$ Department of Sociology and Anthropology, Benson Idahosa University \\ ${ }^{2}$ Department of Political Science \& Public Administration, Benson Idahosa University, \\ Benin City, Nigeria \\ *email: uhunmwuangho4you@yahoo.com
}

\section{Abstract}

The paper examines the Sociological Implication of State Creation in Nigeria and the Means of Resolving the Unforeseen Dispute. State creation in a Federation is primarily aimed at promoting unity in diversity particularly among the various ethnic groups in a heterogeneous country such as Nigeria. The creations of states are also aimed at resolving boundary disputes and promote national development. However, the multiplication of states on the other hand, translates to the multiplication of administrative agencies particularly the bureaucracy. The constant increase in the number of these administrative agencies no doubt has a lot of consequences for their viability, crises, effectiveness and efficiency. This is because it weakens the administrative capacities of these bureaucracies since their existence and indeed their survival in terms of finances depends almost entirely on the central government. This paper infers that the exercise of uncontrolled creation of more states in Nigeria requires radical reorientation coupled with strong sociological/political will for public bureaucracies at the state level to be able to meet their developmental and efficiency goals. In the course of this study, the Sociological Implication of State Creation and The Means of Resolving the unforeseen Dispute in Nigeria were brought to the fore while the objectives of the study are well spelt out. Hypotheses were postulated and the Modern Conflict Theory was used to explicate the works. Data were obtained from both primary and secondary sources. From the primary sources, the survey method, that is, the use of questionnaire designed and adopted. Data obtained from this method were analyzed with the aid of Simple Percentage. Thereafter, the five researchable hypotheses were tested and accepted while the null hypotheses were rejected. The implication is that there was relationship between the dependent and independent variables. Generally, the paper brought to focus that the Sociological Implication of State Creation and the Means of Resolving the unforeseen Crises is a collective effort in reaching a compromise in the management of Nigeria Political and Sociological affairs and it has contributed immensely to the growth and development of crises management else-where. The paper painstakingly appraises many of these issues and concludes that all stakeholders in the federal polity should thread softly, be objective, rational, altruistic and magnanimous in order not to make the existence of true federalism (sociological, political and economic cohesive existence of the people, peace and tranquility) a fleeting illusion and a mirage.

Keywords: State, Ethnic, Politics, Bureaucracy, Crises, Creation

DOI: $10.7176 / \mathrm{JCSD} / 67-04$

Publication date: February $28^{\text {th }} 2022$

\section{Introduction}

Nigeria nation, more than anything else, the greatest obstacle to the nascent democracy is the pervasive insecurity of lives and property, as evidenced by the spate of armed robbery attacks, political assassinations, power distribution coupled with the seeming helplessness of security agencies to handle criminal acts. The situation is worsened by the increasing number of unemployed Nigerians some of whom are ready recruits for criminal activities. The above statement from an editorial comment by a national daily in Nigeria indeed, epitomizes the central focus of this paper, the aim of which is to analyze the nexus between democratic nurturing, sustenance and eventually consolidation via-a-vis the battles with one of the major ills of Nigeria nation. Sixty one years after Independence, Nigeria still battles with one of the major fall-outs of democratic dispensation, the creation of states and bureaucratic bottlenecks, the Sociological Implication of State Creation and politics of trying to appease all sectors of the polity. However, Governments all over the world play important roles in the distribution of goods and services to the citizens. This role performance comes in form of decisions taken to give direction to the day to day running of state affairs (Uhunmwuangho and Epelle, 2011). When seen as policy, a government decision could be distributive, re-distributive, regulatory or even symbolic depending on the effects it has on the lives of the citizens. These effects are particularly pronounced in Africa where small changes in resource allocation by the central government affect the ability of other levels of government to provide public services (Uhunmwuangho and Epelle, 2011).

However, Nigeria is a plural society with different cleavages - ethnic, religious, cultural, linguistic, as well as geo-political, social and economic development - but ethnic heterogeneity is inarguably, the most pervasive of them all. The problem of that ethnicity poses is that political competition and access to power is 
overtly drawn along ethnic lines. Again, since Nigerian Federalism is based on ethnic and not geographical diversities, it has tended to exacerbate centrifugal forces in the country. Therefore, the struggle for acquisition and access to power in Nigeria has been patterned largely along ethnic lines. This becomes more problematic because the State is not a neutral force in mediating political conflict. It can be captured and used to further the interests of the leadership of an ethnic group or a combination of such groups (Vande, 2015).

Thus, there seems to be no limit to the demands for States creation in Nigeria, for as long as ethnic chauvinists and political merchants keep agitating for State creation in order to solve the alleged marginalization of their people. It seems irrelevant to these professional agitators and political opportunists whether or not their prospective States posses the capacity to survive. To worsen matters, each ethnic group has continuously come to think of itself as a distinct entity with interests and demands. Again, "there has been unabated clamour and agitations for the creation of more States to satisfy ethnic nationalism. While ethnic or separatist nationalism grow to the detriment of Nigerian nationalism, there has been a growing attitude of antagonisms and lack of trust among Nigerians (Vande, 2015).

This paper seeks to explore the roots and nature and Sociological Implication of State Creation and Means of Resolving Unforeseen Crises of ethnic politics in Nigeria, especially as it relates to the agitation and the actual creation of States to satisfy ethnic sentiments. The paper argues that as a Nigerian people, the various ethnic nationalities need to learn to live together rather than clamouring for more States. This is because the creation of more States will multiply the existing problems and/or crises - ethnic minority issues, lack of development, corruption, the bankruptcy of the States and a Unitarist Federation, therefore, adversely affecting the overall growth, development and national integration of the country (Abdusalami, 1998).

Consequently the emerging issues include:

1. Does the State Creation have viable tools for addressing injustice in the System?

2. Does Ethnicity pervade the top management for greater administrative responsibilities in the System?

3. To what extent does the State Creation provide specialized advisory services to the Management of Nigeria State?

4. Does the Stakeholders foresee the Crises State Creation are likely to bring?

5. To what extent does the State Creation provide the premise for training young sociological/politicians to take over the management of the Enterprise in Nigeria?

\section{Problems}

The Federal structure of Nigeria is believed to be 'a bad marriage that all dislike but dare not leave, and that there are possibilities that could disrupt the precarious equilibrium in Abuja' (Ogbe et al., 2015). The dominant conceptual and legal foundation for Nigerian internal sociological, political, geographical is ethnicity and the politics of State Creation in Nigeria . A federal arrangement was expected to be instrumental for forging national unity out of the plural society and at the same time in preserving the separate social identities cherished by its component parts.

It has therefore become a recurring phenomenon in the contemporary Nigerian State among Nigerian citizenry to question the relevance of State Creation to nation building and national development. Thus, some scholars have argued vehemently for its abolition while others have supported its continued existence within the political system of Nigeria. Ademolekun have argued that ethnicity has never worked for the progress of Nigeria. He further stated that right from the slave trade era to the 19th century, the ethnic groups have continued to be self-centred individuals, parochial and clannish (Ademolekun, 2003).

The exercise for State Creation has generated more questions than the answers it provided. For instance, the advocates for the majority groups saw the minorities as the main beneficiaries of the exercise and questioned the implicit attempt to make minorities equal to majorities. They, accordingly, demanded more States for the majorities to reflect the population differences. Another problem was the appearance of new minorities and fears of domination. Furthermore, Hembe (2010) posits that the North-Eastern State alone accounted for about 1/3 of the total land area of Nigeria, leaving the remaining 2/3 to the other eleven States. In view of these and other complaints and problems, Gowon promised that he would review the whole issue of State creation after the war. This promise heightened the tempo of demands for new States, but no concrete effort was taken to review the exercise until he was overthrown in 1975.

Politics and Sociology is a pervasive human endeavour that prevails in all spheres of life that is as old as human history. Given the nature and character of politics, it has witness a plethora of definitions. Politics has however been defined by Harold Lasswell as an empirical science that studies the shaping and sharing of power about "who gets what, when and how (Lasswell, 1930)". This implies that politics extend beyond the realm of State affairs. It therefore bothers on whether power - the main object of politics - is obtained as an end in itself to ensure binding decisions or as a means to an end. Another Political theorist, David Easton, defines politics as the persistent pattern of human interaction in a society mainly oriented towards "authoritative allocation of values." This indicates that politics has to do with authoritative or binding decisions concerning the distribution of State's 
resources. Easton's definition suggests that once a decision is made, it conveys the idea of legitimacy and binding compulsion. This covers the realm of public politics because resolutions are authoritative within the structures of government (Easton, 1965) .

In a nutshell, politics can be said to refer to all the issues and events that involve the struggle for acquisition and use of power and all the benefits and resources it confers. Politics, therefore deal with the State and the political society - that is, a people organized for law within a definite territory.

\section{Objectives}

The specific objectives are:

(a) To determine whether State Creation have been viable tools for addressing injustice in the System.

(b) To ascertain to what extent the Ethnicity pervade the top management for greater administrative responsibilities in the Nigeria System.

(c) To ascertain the extent to which the Stakeholders foresee the Crises State Creation are likely to bring.

(d) To examine the extent to which the State Creation have help the citizenry for greater hopes.

(e) To establish whether State Creation provide the premise for training young sociological/politicians to take over the management of the Enterprise in Nigeria?

\section{Hypotheses}

In order to achieve these objectives, the following research hypotheses were formulated:

1. There is no significant relationship between State Creation and viable tools for addressing injustice in the Nigeria System.

2. There is no significant relationship between ethnicity and pervading the top management for greater administrative responsibilities in the Nigeria System.

3. There is no significant relationship between the extent to which the Stakeholders foresee the Crises and State Creation are likely to bring.

4. There is no significant relationship between the State Creation and the citizens greater hopes.

5. There is no significant relationship between the State Creation and provision for the premise for training young sociological/politicians to take over the management of the Enterprise in Nigeria

\section{Theoretical Exposition}

The particular theory that can sufficiently act as guide for the analysis of issues in this paper is the Modern Conflict Theory as propounded by Wright Mills, who is called the founder of modern conflict theory. Conflict theory generally is based on the writings of Karl Marx and Friedrich Engels. The theory, as propounded by Wright Richards (2009) argues that society is not best understood as a complex system striving for equilibrium but rather for competition. It further maintains that society is made up of individuals and groups for limited resources, for instance, money, leisure, opposite partners, etc. Again, broader social structures and organizations, like religious, governments etc, reflect the competition for resources in their inherent inequalities; some people, groups and organizations have more resources - power and influence - and use those resources to maintain their positions of power in society. Conflict theory was developed to illustrate the limitations of structural - functionalism. The structural-functionalist approach argued that society tends towards equilibrium, focusing on stability at the expense of social change. This is contrasted with the conflict approach which argues that society is constantly in conflict over resources (Vande, 2015).

The main assumptions of the conflict theory are that, first; competition over scare resources is at the heart of all social relationships. Competition, rather than consensus is characteristic of human relationships. Secondly, the theory assumes that inequality in power and reward are built into all social structures. Individuals and groups that benefits from any particular structure strive to see it maintained. Thirdly and lastly, the theory assumes that change occurs as a result of conflict between competing interests rather than through adaptation. It insists that change is often abrupt and revolutionary rather than evolutionary. A heuristic devise to help us think about society from a conflict perspective is to ask, "Who benefits from this element of society"? Using the same example, we can ask, "Who are the main beneficiaries of States creation in Nigeria"? Who are the actors that campaign against ethnic injustice and what are their interests?

\section{Literature:}

\section{The Politics of States Creation in Nigeria}

There have been continuous calls for more States in Nigeria, even as the National Assembly started amending the 1999 Constitution. The agitators for more States argue that States creation will bring development closer to the door-steps of many Nigerians. Esogbue maintains that "creation of more States has brought development economically to the door steps of many towns and cities, many of which have been labeled, as 
capital cities or headquarters. He submits further that with the creation of more States the scope of political development will be widened to accommodate 36 Governors, 36 Houses of Assembly, more legislators, more State High Courts, more police officers, etc. He also assert that more States will also see to the citing of the headquarters of several Parastatals, Ministries, Federal and State Universities as well as other modern developmental structures like Airports, Banks etc (Esogbue, 2012)

The agitators for States creation also maintain that such an exercise will create an opportunity for the marginalized people or ethnic groups to have access to power. In their argument, the Federal Executive Council is rested on the number of States in existence, and that most times decisions are democratically reached by the body through votes. This will therefore give some regions or ethnic groups more weight in their bargain for the allocation of values. They also maintain that by creating new bureaucracies, it will give mass employment to youths and other qualified graduates. Since the inception of his tenure as the Senate President of the National Assembly in 2007, Senator David Mark has not left anyone in doubt about his desire to increase the number of States in the country through the creation of more States. This has no doubt renewed the hope of agitators for creation of new States.

The agitations for new States in the present democratic dispensation (1999 till date) reached a crescendo in 2005 during the inconclusive National Political Reform Forum convened by the administration of former President Olusegun Obasanjo (1999 - 2007). In that Conference, the Igbo delegates from the South East who feel short-changed by the present structure in the country had gone to the Conference with the creation of an additional State for the zone as its main agenda. In their argument, the South-East has only five States against six States in the South-West, South-South, North-Central, North-East and North-West, which has seven. Although this dream did not materialize in that Conference, it has not doused the demand of the zone for at least one additional State in the spirit of fair play and equity. Today, it is not only the South-East that wants more States. After concluding a recent National Conference in Abuja, the former Deputy Senate President, Senator Ike Ekweremadu hinted that, the demands for additional States now stands at forty-five. He also pointed out that "ethnic minority fears, search for equity and speedy developments as well as quest for political empires and influence by the elite are key factors determining the clamour for more States". According the former Deputy Senate President the country would become a Federation of 81 States, should all the requests be granted.

Furthermore, the creation of States has always being influenced by political rather than developmental considerations. For instance, the creation of the Mid-Western State in 1963 was done out of the conspiracy by the coalition government of NPC/NCNC to divide the opposition AG's stronghold. The creation of 12 States by Gowon was also believed to have been motivated by the desire to whittle the influence of the then Governor of Eastern Region, Chukwuemeka Ojukwu at the height of hostilities between the Region and the Federal Government. In the subsequent exercises, the struggle for "access to the ,national cake ${ }^{\text {ee }}$ has been the main consideration in the creation of States. In many cases, champions push for creation of new States for their people, not because the people are in support of such moves, but because they want political freedom for themselves or they want to prove a point to their political opponents (Uhunmwuangho and Epelle, 2011).

\section{Methodology}

This paper adopted a descriptive survey method. The survey was based on selected Geo-political Zones in Nigeria political system. The States are Abia (South East), Anambra (South East), Bauchi (North East), Borno (North East), Bayelsa (South South), Edo (South South), Kano (North West and Katsina (North West). The scope of the study is therefore restricted to years 2000 to 2019. The population of the study consist of 250 base on two categories (Senior and Junior) members of staff Public Service (See Table One Below). Out of this number, one hundred and seventy of them met our criteria and therefore form our sample size as can be seen in table one below: 
TABLE 1: POPULATION OF STUDY

\begin{tabular}{|c|c|c|c|c|c|}
\hline S/No & State/Geo-political Zone & $\begin{array}{l}\text { Category of } \\
\text { Respondents }\end{array}$ & $\begin{array}{l}\text { No. of Returned } \\
\text { Questionnaires }\end{array}$ & $\begin{array}{l}\text { No. of Not } \\
\text { Returned/Invalid } \\
\text { Questionnaires }\end{array}$ & $\begin{array}{l}\text { Total No. of } \\
\text { Sampled } \\
\text { Respondents }\end{array}$ \\
\hline \multirow[t]{2}{*}{1.} & \multirow[t]{2}{*}{ Abia (South East) } & Senior Staff & 16 & 6 & \multirow[b]{2}{*}{31} \\
\hline & & Junior Staff & 5 & 4 & \\
\hline \multirow[t]{2}{*}{2.} & \multirow[t]{2}{*}{ Anambra (South East) } & Senior Staff & 17 & 8 & \multirow[b]{2}{*}{31} \\
\hline & & Junior Staff & 4 & 2 & \\
\hline \multirow[t]{2}{*}{3.} & \multirow[t]{2}{*}{ Bauchi (North East) } & Senior Staff & 18 & 7 & \multirow[b]{2}{*}{32} \\
\hline & & Junior Staff & 4 & 3 & \\
\hline \multirow[t]{2}{*}{4.} & \multirow[t]{2}{*}{ Borno (North East) } & Senior Staff & 15 & 7 & \multirow[b]{2}{*}{31} \\
\hline & & Junior Staff & 6 & 3 & \\
\hline \multirow[t]{2}{*}{5.} & \multirow[t]{2}{*}{ Bayelsa (South South) } & Senior Staff & 17 & 6 & \multirow[b]{2}{*}{32} \\
\hline & & Junior Staff & 5 & 4 & \\
\hline \multirow[t]{2}{*}{6.} & \multirow[t]{2}{*}{ Edo (South South) } & Senior Staff & 17 & 8 & \multirow[b]{2}{*}{31} \\
\hline & & Junior Staff & 4 & 2 & \\
\hline \multirow[t]{2}{*}{7.} & \multirow[t]{2}{*}{ Kano (North West) } & Senior Staff & 18 & 7 & \multirow[b]{2}{*}{31} \\
\hline & & Junior Staff & 4 & 3 & \\
\hline \multirow[t]{2}{*}{8.} & \multirow[t]{2}{*}{ Katsina (North West) } & Senior Staff & 16 & 6 & \multirow[b]{2}{*}{31} \\
\hline & & Junior Staff & 5 & 4 & \\
\hline TOTAL & & & 170 & 80 & 250 \\
\hline
\end{tabular}

Source: Field Survey 2021.

Both Primary and Secondary sources of data were explored in trying to generate data for this study The specific information required for the study was The Sociological Implication of State Creation and Unforeseen Crises of the Federal System of Nigeria. The questionnaire formed the main instrument used in generating primary data, while documented information on prints that are relevant to this study, constituted the secondary source of generating data. To compliment the information received through the questionnaire, respondents were also interviewed. As the research is based on attitude and opinions, the statistical tools employed in analyzing responses include, tables and simple percentages. All the one hundred and seventy copies of the questionnaire distributed to the respondents studied were duly completed and returned in a useable form. The Statistical Package for Social Sciences (SPSS) was used for the data analysis.

\section{Demographic Data}

Of all the one hundred and seventy respondents, eighty (47\%) of them are married; fifty (29\%) are single while twenty one (13\%) are divorced and the remaining nineteen $(11 \%)$ are either widow or widowers. Thirty (18\%) of them are within the age bracket of $18-25$, Fifty $(29 \%)$ are between the age bracket of 26-35; while eighty $(47 \%)$ are within the age bracket of $36-45$ and the remaining forty six years and above are ten $(6 \%)$.

TABLE 2: Hypothesis 1

There is no significant relationship between State Creation and viable tools for addressing injustice in the Nigeria System.

\begin{tabular}{|l|c|c|}
\hline Responses & No. of Respondents & Percentage \\
\hline Yes & 110 & 65 \\
\hline No & 60 & 35 \\
\hline Total & 170 & 100 \\
\hline
\end{tabular}

\section{Source: Statistical Analysis}

Table 2 shows that $110(65 \%)$ of the total respondents agreed that State Creation have viable tools for addressing injustice in the Nigeria State have more relevance and impacted negatively on people enjoying the dividends of democracy in Nigerian's political system in particular and conversely responsible for the lack of poor performance of our elected legislators and fragrant disregard for rules and regulations.

Therefore, the hypothesis one which states that there is no significant relationship between State Creation and viable tools for addressing injustice in the Nigeria System is accepted. 
TABLE 3: Hypothesis 2

There is no significant relationship between ethnicity and pervading the top management for greater administrative responsibilities in the Nigeria System.

\begin{tabular}{|l|c|c|}
\hline \multicolumn{1}{|c|}{ Responses } & No. of Respondents & Percentage \\
\hline Yes & 105 & 62 \\
\hline No & 65 & 38 \\
\hline Total & 170 & 100 \\
\hline
\end{tabular}

Source: Statistical Analysis

Table 3 shows that $105(62 \%)$ of the respondents agreed that there is correlation between ethnicity pervading the top management for greater administrative responsibilities in the Nigeria System which led to slow developmental and suffering of masses in the midst of plenty, while $65(38 \%)$ were not satisfied or disagreed.

\section{TABLE 4: Hypothesis 3}

There is no significant relationship between the extent to which the Stakeholders foresee the Crises of State Creation are likely to bring.

\begin{tabular}{|l|c|c|}
\hline \multicolumn{1}{|c|}{ Responses } & No. of Respondents & Percentage \\
\hline Yes & 120 & 71 \\
\hline No & 50 & 29 \\
\hline Total & 170 & 100 \\
\hline
\end{tabular}

Source: Statistical Analysis

Table 4 shows that $120(71 \%)$ of the respondents agreed that State Creation are likely to bring unimaginable crises which will stall continuous democracy to the citizenry while $50(29 \%)$ disagreed with the opinion.

Therefore, the hypothesis which states that there is no significant

relationship between the extent to which the Stakeholders foresee the Crises of State Creation are likely to bring nation-wide which conversely will lead to lack of dividends of democracy to the citizenry in Nigeria is accepted.

\section{Findings Based On Hypotheses}

Based on the analysis of the hypotheses, all the research hypotheses were positive which implies that

(Hr) 1-3 were accepted.

More so, the study revealed that that agreed that there is correlation between ethnicity pervading the top management for greater administrative responsibilities in the Nigeria System which led to slow developmental and suffering of masses in the midst of plenty conversely led to lack of dividends of democracy in Nigeria.

1. Furthermore, this paper have highlighted several challenges and solutions as per the findings in the hypothesis carried out in the research. However, again, it was found that the Implication of State Creation will not only lead to more development in the country but will also aggravate more crises which one cannot foresee in the near future (Adele, 2005).

2. It was revealed that the developments in recent times have whittled down. Several organizations normally focus attention on the other means of resolving conflicts in their activities and functions. State Creation in this wise will not only worsen the already battered economy but will lead to division of the economy as being agitated by so many ethnic groups in Nigeria.

3. It was also revealed according in the findings that the major view held by the respondents that the clamour for State Creation has always been reoccuring deciman which if this not quickly addressed will lead to the nation helding towards anarchy (Elaigwu, 2005).

4. Finally, the study also revealed that federalism in Nigeria has failed to unite the country, because rapid and even development across the length and breadth of the country and has failed to checkmate the many recent expressions of ethnic, religious and cultural bigotry that has led to deaths of many innocent and unarmed Nigerians, young and old, Dora Akunyili's husband untimely death is a pointer. See below the political map of Nigeria.

See figure 1 below for more details of Nigeria Political map. 


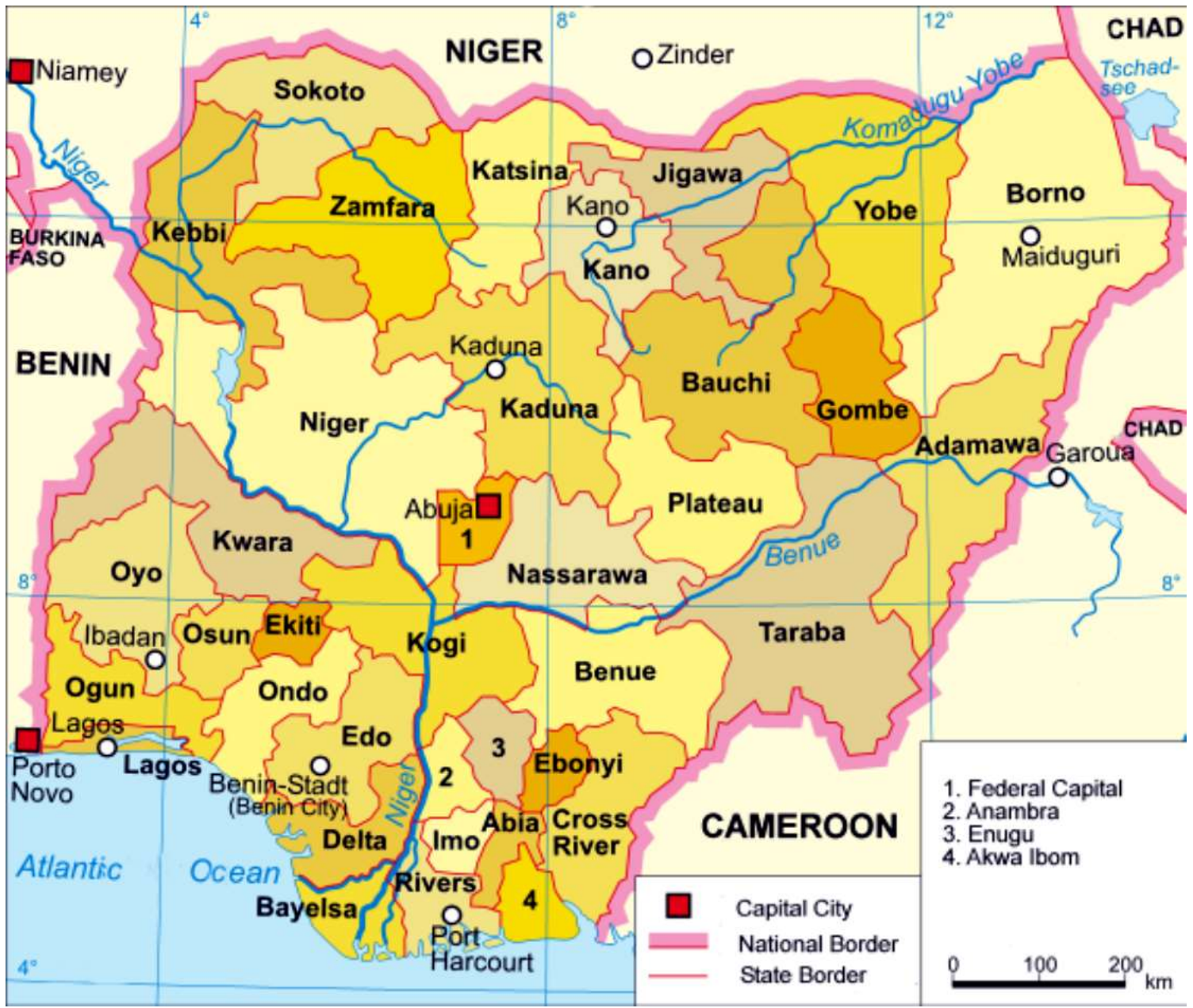

Figure 1: Political map of Nigeria

Source: Wilkipedia catched 20 November, 2021

\section{Conclusion And Recommendations}

In conclusion, the Nigeria sovereign nation, more than anything else, the greatest obstacle to the nascent democracy and Sociological and Political aspiration is the pervasive insecurity of lives and property, as evidenced by the spate of armed robbery attacks, political assassinations, religious conflicts and ethnicity of politics of state creation coupled with the seeming helplessness of security agencies to handle criminal acts (Uhunmwuangho and Epelle, 2011). The situation is worsened by the increasing number of unemployed Nigerians some of whom are ready recruits for criminal activities (Nigerian Tribune, 2002). The above statement from an editorial comment by a national daily in Nigeria indeed, epitomises the central focus of this paper; the aim of which is to analyze the nexus between democratic nurturing and to sustain the current debate on sustainable democratic dispensation and Sociological and Political sustainability in the 21 st century, which is a topical issues in Africa in general and Nigeria in particular.

Ethnicity among other socio-political issues has a lot of implications for the Nigerian project. The struggle among ethnic groups to have access and control resources in Nigeria nearly delayed the country's independence due to the fear of domination expressed by the different ethnic groups. It is this struggle among the various ethnic groups that led to the struggle for States creation in Nigeria. The struggle which began before independence has continued unabated, despite the balkanization of the country into thirty- six (36) States from the initial three (3) regions. The creation of States to satisfy parochial and patrimonial needs will not move the country forward. States creation is not, in the least, a solution to the myriad of problems the country is facing. Previous exercises have never been done from the perspective of bringing government and development closer to the people. Rather, it has been to score some political goals and satisfy particular interests. Again, experience has shown that States creation in Nigeria over the years has not brought about the desired or expected effects. There 
has been no sustainable development in the States, the structures are unviable, dependent on the Federal Government and have become dens of corruption and underdevelopment (Jinadu, 2008).

What the country needs is a transformational, visionary and courageous leadership. It is evident that the creation of new States is an uncreative means of dealing with the aspects of national development. The creation of States is therefore not a solution to the problems of development and democracy in Nigeria. Rather, the exercise will create opportunities and developments which will liberate new forces and threw up more challenges. The present Federal structure in the country is unitarist. Nigeria runs a system of government that grants near absolute power to the Federal Executive. We therefore recommend a Constitutional amendment and efforts that will ensure true Federalism, rather than creating unviable and dependent States. Again, the States should be allowed to control up to $50 \%$ of their resources. This will reduce the number of agitations for new States because many of the proposed new States have no economic basis to sustain themselves, except their dependence of Federal revenue. It will also encourage States to look inward for internally generated revenue by diversifying the economy (Adeyemi, 2011).

Again, the continued agitations for the creation of more States are simply an easiest way of having access to power and wealth. To actually get the government and development to the people, there is need to reposition the Local Government, which is the closest tier of government to the grassroots. For now, the Local Governments are operating under the strangulating control of State Governors. They are centers of corruption and mediocrity. The powers and functions of the Local Government system should be enshrined in the Constitution and their finances ensured. One of the reasons for an endless clamour for more States is the cry of marginalization by some purported minorities. Yet Nigerian is a heterogeneous State of more than 374 ethnic groupings. If every dominated and/or marginalized group wants a State of its own as a solution to its problems, how many States will Nigerian have? The State and Federal Government authorities should therefore create structures and make provisions for peaceful co-existence among the various groupings in the country. There should be Constitutional arrangements which will guarantee the rights of all nationalities, especially, the rotation of elective offices among the various nationalities to avoid crises (Wikipedia, 2015).

\section{R e f e r e n e s}

Abdusalami .I. (1998) The Structure and Functions of the Civil Services in Nigeria, in Ngu, Abdusalami I. and Longe, J.B (Eds) Evolution of Nigeria Civil Service - The 1988 Reform, Zaria: Gaskiya Corporation Limited.

Adele J. (2005) Federalism, the Consciational State and Ethnic Conflict in Nigeria, Journal of Federalism, Vol. 15. 71, accessed March 9, 2015. www.publius.oxfordjournals.org.

Ademolekun, L. (2003) Politics, Bureaucracy and Development in Ibadan, spectrum Books Limited.

Adeyemi, A. (2011) “Dangers of State Creation”. Tell Magazine. Accessed 9th November, 2011. www.tellng.com.

Easton, D. (1965) A Framework of Political Analysis (Englewood: Prentice Hall. Editorial Comment, (2002). Three years of Democracy. Nigerian Tribune, Vol. 1, pp. 10.

Elaigwu, I. (2005) The Politics of Federalism, Jos: Aha Publishing House.

Esogbue, E. (2012) Still on the Need for State Creation in Nigeria”. Nigeria News Online, accessed 24th January, 2015, www.nigeriannewsonline.com

Hembe, G. (2010) The Logic of More States and the Nature of Nigerian Federalism. African Journal of Economy and Society, Vol. 2 No. 2.

Lasswell, H. (1930) Politics: Who Gets What, When and How (New York: World Publishing Company.

Ogbe O, Max M, Shija M.D. and Zever A.T., (2015). The Need For Reform of Fiscal Federalism in Nigeria, Benue State. National Journal of Human Resource Development, Vol. 1, No. 1

Uhunmwuangho S.O. and Epelle A, (2011). Challenges and Solutions to Ethno-Religious conflicts in Nigeria: Case Study of Jos Crises. Journal of Sustainable Development in Africa, Vol. 13 No. 5.

Vande, P.T. (2015) Ethnicity and the Politics of State Creation in Nigeria, Abuja, Veritas University Press, Wright, Richard (2009), Kidnap for Ransom: Resolving the Unthinkable, London and New York: CRC Press.

Wiki Books (2015) Introduction to Sociology. Sociological Theory, Last Modified April 17, 2016, www.en.wikibooks.org

\section{Website:}

Wikipediahttp://enwikipedia.org/wiki/Statecreation.22, accessed on $12^{\text {th }}$ May, 2021

Wikipedia, (2015) Heal Nigeria, On State Creation and Constitutional Review, accessed 9th November, 2015, www.healnigeria.hlogspot.com 